doi https://doi.org/10.31977/grirfi.v22il.2622

Recebido: 03/09/2021 | Aprovado: 12/02/2022

Received: 09/03/2021 | Approved: 02/12/2022

\title{
DILECTIO, RESIGNAÇÃO E INJUSTIÇA: POSSIBILIDADE DE INTERPRETAR O AMOR COMO RESIGNAÇÃ̃ E CONFORMAÇÃO COM A INJUSTIÇA, À LUZ DE SANTO AGOSTINHO
}

\author{
Ricardo Evangelista Brandão ${ }^{1}$ \\ Instituto Federal de Pernambuco (IFPE) \\ (i) https://orcid.org/0000-0003-2217-4661 \\ E-mail: ricardobrand75@gmail.com
}

\section{RESUMO:}

No "Comentário da primeira Epístola de São João", em específico fragmento do texto em que o foco é a controvérsia donatista, Agostinho afirma que a despeito do fato de que o amor é norma incontornável à verdadeira vida cristã, no caso de testemunhar uma ação injusta, o cristão não pode aceitar passivamente a tal ato. Todavia, nesse mesmo texto, em outro contexto, é defendida uma espécie de resignação como prova de que o cristão de fato está vivendo uma prática cristã eivada pelo amor de Deus. Na De civitate Dei Livro XIX, no "Sobre os costumes da igreja católica e dos maniqueus", e em outras obras, o mesmo paradoxo persiste: se por um lado o filósofo cristão reconhece que mesmo vivendo em intensa dor e sofrimento é possível se conformar e encontrar a paz, uma paz possível ante a situação, por outro lado, defende que não é justo um homem se submeter a outro visto que somos ontologicamente iguais, logo, aparentemente não incentivando a eupatia nessa injusta situação. Assim, é nossa meta nessa comunicação: investigar como podemos compreender a relação do amor com a resignação, e se ambos os conceitos podem ser aplicados às situações de flagrante injustiça vividas ou testemunhadas.

PALAVRAS - CHAVE: Dilectio; Injustiça; Resignação.

\section{DILECTIO, RESIGNATION AND IUSTITIA: POSSIBILITY OF INTERPRETING LOVE AS RESIGNATION, AND CONFORMITY WITH INJUSTICE, IN THE LIGHT OF SAINT AUGUSTINE}

\begin{abstract}
:
In the "Commentary on the First Epistle of St. John", in a specific fragment of the text in which the focus is the Donatist controversy, Augustine states that despite the fact that love is an unavoidable norm for the true Christian life, in case of witnessing an action unjust, the Christian cannot passively accept such an act. However, in that same text, in another context, a kind of resignation is defended as proof that the Christian is in fact living a Christian practice permeated by the love of God. In De civitate Dei Livro XIX, in "On the customs of the Catholic Church and the Manicheans", and in other works, the same paradox persists: if on the one hand the Christian philosopher recognizes that even living in intense pain and suffering it is possible to conform and finding peace, a possible peace before the situation, on the other hand, defends that it is not fair for a man to submit to another since we are ontologically equal, therefore, apparently not encouraging eupathy in this unfair situation. Thus, our goal in this communication is: to investigate how we can understand the relationship between love and resignation, and whether both concepts can be applied to situations of flagrant injustice experienced or witnessed.
\end{abstract}

KEYWORDS: Dilectio; Iustitia; Resignation.

\footnotetext{
${ }^{1}$ Doutor(a) em Filosofia pela Universidade Federal de Pernambuco (UFPE), Recife - PE, Brasil. Professor(a) do Instituto Federal de Pernambuco (IFPE), Caruaru - PE, Brasil.
}

BRANDÃO, Ricardo Evangelista. Dilectio, resignação e injustiça: possibilidade de interpretar o amor como resignação e conformação com a injustiça, à luz de Santo Agostinho. Griot : Revista de Filosofia, Amargosa - BA, v.22 n.1, p.251-265, fevereiro, 2022. 


\section{Introdução}

Os termos latinos dilectio, amor e caritas significam amor, e embora Agostinho em algumas obras utilize os termos de forma livre, com significados intercambiáveis e até como sinônimos como no De civitate Dei, em outras obras como In epistolam Ioannis ad Parthos (Comentário da primeira epístola de São João) no próprio texto esclarece a distinção que faz entre os termos amor e dilectio, sendo o primeiro um termo autorizado a ser usado para objetos inferiores, como quando se diz que se ama determinada refeição, todavia igualmente pode ser utilizado para objetos superiores. Já dilectio é utilizado para objetos mais elevados como para expressar a devoção a Deus (Cf. AGOSTINHO, In ep. Joan. ad Parthos VIII, 5)². Dessa forma, levando em consideração a eloquência no uso das palavras e expressões da pena do filósofo, que o faz atribuir sentidos diversos ao sabor das circunstâncias e contextos, na prática o que determina o significado de dilectio, amor e caritas nas obras do filósofo é o contexto em que as palavras são usadas. Esse amor com sentido mais elevado do termo dilectio presente no "Comentário da primeira epístola de São João", independente de quais dos três termos latinos o filósofo utiliza, é decorrente de uma conversão ao amor de Deus, e, por conseguinte por uma metafísica imersão no amor divino, habilitando assim o cristão a amar a Deus e ao próximo com o amor de Deus. Isto posto, doravante nesse artigo trabalharemos os termos dilectio, amor $e$ caritas com o sentido de amor a objetos mais elevados, como a dilectio utilizada no "Comentário da primeira epístola de São João", claro que sempre respeitando a intenção do autor ditada pelo contexto de uso dos termos. Assim, amor, sempre que o contexto permitir, será interpretado como um sentimento que predispõe uma inclinação ao objeto amado, tornando esse objeto um pondus que direciona a vida, decisões e ações do amante em direção do objeto amado, objeto esse de ordem superior como Deus e o próprio homem.

Após essas breves mas necessárias observações acerca de como significar a dilectio, nos cabe doravante compreender se podemos interpretar a dilectio como uma resignação ${ }^{3}$ ao sofrimento de si mesmo e do próximo, ou pelo contrário, se o verdadeiro amor impossibilita esse conformar-se com os tormentos mencionados. Para esclarecer e refletirmos sobre o problema posto à luz do pensamento de Agostinho, elencamos como objeto de análise alguns fragmentos de quatro obras do pensador que lançam importante luz sobre a questão, notadamente: De vera religione, De moribus Ecclesiae Catholicae et de moribus manichaeorum, In Epistolam Ioannis ad Parthos tratactus decem, De civitate Dei. No primeiro capítulo examinaremos as duas primeiras obras, que inclusive foram escritas em períodos muito próximos, notadamente entre 387 - 391, revelando as reflexões de Agostinho sobre o assunto pouco tempo depois de seu batismo, período marcado pelo batismo, tentativa de ócio filosófico e o começo da ordenação sacerdotal. E no segundo capítulo abordaremos a temática por meio da análise de fragmentos das duas últimas obras listadas, escritas em 416 e 413-426 respectivamente, fase intelectual de um Agostinho bispo, maduro na fé que adotou, e com muitas responsabilidades civis e eclesiásticas.

\footnotetext{
2 Ver também AGOSTINHO, De ver. rel. XLVII, 91.

3 O termo resignação nesse texto detém o seguinte significado: se conformar com uma situação de dor e sofrimento, sendo, portanto, uma forma de sujeição tranquila aos infortúnios, dificuldades, penúrias, fatalidades e até injustiças da vida (Cf. FERREIRA, 1986, p. 452, 1493).
} 


\section{Resignação e o amor ao próximo à luz das obras: De vera religione e De moribus ecclesiae Catholicae et de moribus manichaeorum}

Começando por um dos primeiros escritos entre os mencionados, o "A verdadeira religião" escrito entre 389-3914, período esse entre a tentativa de ócio teológico-filosófico e a ordenação sacerdotal de Agostinho, escrito na intenção de apresentar a verdadeira religião aos amigos que outrora o viram apregoar o maniqueísmo, como o seu benfeitor Romaniano. Dessa forma temos uma obra em que Agostinho contava com 36 anos, e com aproximadamente três anos de conversão à fé cristã quando começou a redigir o livro, se tratando assim de um Agostinho jovem, e embora sem longa vivência na fé e com poucas responsabilidades no cristianismo, não podemos considerá-lo como um neófito nesse período ante ao teor do texto em análise.

Destarte, em certo trecho da "A verdadeira religião" o pensador descreve o que em sua compreensão seria o homem justo que foi inundado pelo amor de Deus, e ao descrever essas características estabelece que esse homem dispõe de uma capacidade para suportar tribulações diversas, devido ao fato de ele saber que seu real repouso e felicidade não está nessa esfera terrena, mas em uma vida mais plena e vindoura com a parousia de Cristo. Esse justo aproveitaria as farturas com moderação, aprenderia com os sofrimentos e até amadureceria espiritualmente com eles, ou seja, o homem justificado pelo amor de Deus é inabalável, pois é cônscio de que nada nessa terra lhe pertence, de forma que esse desapego o capacita a suportar as maiores tormentas sem se entristecer "Para tal homem é pouco não se entristecer com as tribulações. Ele gloria-se delas [...]" (AGOSTINHO, De ver. rel. XLVII, 92)5. Esse estranho regozijo (gaudeat) oriundo da tribulação acontece por dois motivos: por ter condições de se aperfeiçoar interiormente com o sofrimento, e pelo desapego que esse justo sente pelas coisas materiais que nos podem dar conforto e prazer nessa vida terrena. Assim, a pessoa que lutou muito para conquistar muitos recursos materiais, pelo esforço que teve acaba se apegando ao que conquistou, e embora aos olhos de todos possa parecer vencedora, na medida em que perde esses recursos por alguma possível adversidade, o apego a tais bens lhes causará sofrimento, esse supostamente bem sucedido na verdade pode ser considerado fracassado. De forma que o verdadeiro vencedor é o homem que não se apega ao que não depende dele para a manutenção, mas o que se apega às coisas que o perder e o manter dependem absolutamente dele ${ }^{6}$ (Cf. AGOSTINHO, De ver. rel. XLVII, 92).

\footnotetext{
4 A datação das obras que analisaremos nesse texto, terá como base a cronologia das obras de Agostinho presente no primeiro volume da coleção "Obras Completas de San Agustin" da Biblioteca de Autores Cristianos (BAC) organizada por Victorino Capanaga (Cf. CAPANAGA, 1994, v. 1, p. 384-387).

5 "Huic viro in tribulationibus parum est non contristari, nisi etiam gaudeat [...]" (AGOSTINHO, De ver. rel. XLVII, 92 - PL 34).

${ }^{6}$ Essa reflexão de Agostinho lembra muito, nas devidas proporções, as elucubrações do segundo estoicismo, pois, Epíteto nos revela como o grande princípio da sabedoria e consequente felicidade, distinguir entre o que podemos alterar e o que não podemos alterar, e é óbvio que essa distinção por si só não vai adiantar muito na vida se não for seguida pela ação. Dessa forma, depois da ciência que ressaltamos, o homem verdadeiramente sábio deve escolher (proaireses) viver segundo essa distinção, ou seja, se preocupar com o que realmente ele pode alterar, e não desperdiçar suas energias com aquilo que não se pode alterar. "Das coisas existentes, umas estão em nosso poder e outras não estão em nosso poder. Em nosso poder certamente a suposição, o impulso, o desejo, o desvio e numa palavra todas as nossas ações; não estão em nosso poder o corpo, as opiniões, os reinos e numa palavra quantas não são as nossas ações" (EPÍTETO, Manual, I, 1). Quando o homem escolhe viver levando em consideração a sábia distinção que apontamos, não será conduzido à inação, muito pelo contrário aperfeiçoará as suas ações para o que realmente importa na vida, amadurecendo no que deve amadurecer e aproveitando melhor cada instante da vida. Mas se pelo contrário, quando no viver não se considera como norteador das ações essa distinção, se desperdiçará energias com o que não vala à pena, de forma que viverá amaldiçoando a vida e todos ao redor, pois nunca conseguirá tirar o melhor proveito do viver (Cf. EPÍTETO, Manual, I, 3; II, 1, 2).
}

BRANDÃO, Ricardo Evangelista. Dilectio, resignação e injustiça: possibilidade de interpretar o amor como resignação e conformação com a injustiça, à luz de Santo Agostinho. Griot : Revista de Filosofia, Amargosa - BA, v.22 n.1, p.251-265, fevereiro, 2022. 
No mesmo contexto do fragmento citado, Agostinho afirma que o homem que ama Deus de todo o coração se torna invencível, pois a sua principal atenção estará voltada a Deus, e esse Deus lhe trará uma paz e contentamento que independe de circunstâncias exteriores. Além disso, poderíamos questionar, e se o sofrimento for com os outros? Pois uma coisa é ter a capacidade interior para absolver os sofrimentos da vida e resignadamente viver em paz, na medida em que se sabe que como cristão a sua real felicidade não está nesse mundo, e outra coisa bem diferente é perceber a dor e o sofrimento do próximo e ficar em paz com isso. A questão é essa, na medida em que essa resignação do cristão provém justamente do amor a Deus, visto que esse amor a Deus nos exige um amor da mesma qualidade para com o nosso próximo, o sofrimento do outro seria o limite dessa resignação? Vale à pena transcrever o que pensa Agostinho sobre o problema posto:

Quem ama a Deus de todo o coração não se aflige, pois, com a morte de ninguém. Sabe bem que não perece para ele, quem não perece para Deus, pois Deus é o senhor dos vivos e dos mortos. Não fica desesperado pela miséria de ninguém, como também não se sente justificado pela justiça dos outros (AGOSTINHO, De ver. rel. XLVII, 91)7.

A morte não deve causar sofrimento, devido à consciência de que a vida continua após a morte (Deus autem dominus est et vivorum et mortuorum - Deus é senhor dos vivos e dos mortos), de forma que a morte nada mais é que uma passagem para outra etapa de nossas vidas, é uma referência apenas humana da transitoriedade corpórea. Obviamente Agostinho está fiado na tese da imortalidade da alma, visto que Deus continua sendo o Senhor dessa alma imortal, que em algum momento (parousia) receberá corpo (corpo transformado) novamente por meio da ressurreição, pois esse fragmento faz referência ao texto bíblico de Rom., 14, 9, que defende o senhorio universal de Cristo e que todos acertarão as contas com Deus na parousia, no grande tribunal de Deus. Com essa base teológica, certa justificação existe na relação do homem com a morte, todavia, o não sentir empatia com o sofrimento e com as alegrias do próximo fica mais difícil de justificar. Estamos diante de uma forma de apatheia cristã, em que o cristão eivado pela certeza de uma relação futura com Deus se resigna com as mais severas dores, sofridas por si ou pelo próximo.

De fato estamos ante algo muito semelhante à imperturbabilidade estoica, em formato cristão é óbvio, pois essa ampla resignação provém da imersão no amor de Deus, e esse que a alcançou é de fato um sábio na prática da fé. Semelhantemente, como no estoicismo existem diversos níveis de sabedoria, pois o próprio Epíteto entendia não ser ele um modelo de sabedoria estoica, remetendo esse modelo a Diógenes (Cf. REALE, 1994, vol. IV, p. 95). O pensador de Hipona menciona que alguns com nível menor de resignação, não conseguirão não sofrer com as dores do próximo: "Se alguma vez é atingido por demais, pelos perigos ou extravios e dores de outrem, ele aceita o impacto dessa emoção no sentido de ir socorrer, corrigir e consolar o outro. E não ficar ele mesmo transtornado por essas coisas" (AGOSTINHO, De ver. rel. XLVII, 91) .

Essa invencibilidade decorrente da tranquila resignação é possível ser rompida, no caso exemplificado no texto quando diante do sofrimento alheio. Essa exceção apontada é bastante coerente, pois, na medida em que o cristão ama o próximo com um amor de qualidade superior,

\footnotetext{
7 "Non ergo iste affligitur morte cuiusquam, quoniam qui toto animo Deum diligit, novit nec sibi perire quod Deo non perit. Deus autem dominus est et vivorum et mortuorum. Non cuiusquam miseria miser est, quia nec cuiusquam iniustitia fit iniustus. Et ut nemo illi iustitiam et Deum, sic nemo aufert beatitudinem" (AGOSTINHO, De ver. rel. XLVII, 91 - PL 34).

8 "Et si quando forte alicuius periculo, vel errore, vel dolore commovetur; usque ad illius auxilium, aut correctionem, aut consolationem, non usque ad suam subversionem valere patitur" (AGOSTINHO, De ver. rel. XLVII, 91 - PL 34).
} 
semelhante ao despendido a Deus ${ }^{9}$, seria dissonante esse se conformar. Do capítulo 45 até o 48 , Agostinho se concentra em refletir acerca da transformação realizada pelo amor na vida do fiel, e no fragmento citado essa imersão no amor de Deus, visto que o cristão passa a amar com esse amor, não lhe permite a indiferença. Dessa forma, essa aphatheia cristã ${ }^{10}$ teorizada pelo hiponense não pode ser confundida com frieza ante as dores do próximo. Contudo, ao deixar de se conformar com a mencionada situação, não deve permitir que esse sentimento de inconformação se transforme em lamúria, mas deve-se canalizar esse se afetar em direção ao socorro do outro.

A despeito da sensibilidade do filósofo no fragmento analisado, o que nos causa certa estranheza não é a exceção apontada, mas a possibilidade de imperturbabilidade mesmo ante o sofrimento alheio, aliás, pela forma como foi construída a argumentação agostiniana, evidenciase a impressão que o se afetar com essas dores do outro seria o resultado de um menor amadurecimento espiritual, uma vez que até mesmo as vitórias dos outros não nos devem gerar regozijo. O texto não deixa dúvidas quanto a isso, é dito Et si quando (E se alguma vez), quer dizer, a irresignação para com os infortúnios de outrem se alguma vez te afetar se devem tomar

\footnotetext{
9 Nosso filósofo se refere ao amor a Deus, expressando uma devoção elevada e desinteressada, todavia, sem embargo aplica essa qualidade de amor igualmente ao nosso próximo. Ou seja, após a conversão espiritual por meio da aceitação do sacrifício de Cristo na cruz, o agora cristão deve amar ao próximo com esse amor superior, o qual conceituamos na introdução como dilectio, ou simplificando ainda mais, o cristão deve amar ao próximo com o amor de Deus.

10 A despeito de ter mencionado a semelhança das intuições de Agostinho com as reflexões do segundo estoicismo no corpo do texto e em nota de rodapé, é relevante ressaltar que existiu certa influência no movimento monástico cristão (monaquismo cristão) de teorias e modo de vida estoico. De certa forma os ensinamentos estoicos relacionados à aphatheia, em que os afetos externos empanam a verdadeira sabedoria de forma que o sábio se dedicaria ao aperfeiçoamento da alma e do controle das paixões tanto corpóreas como das inquietações advindas do mundo, estão presentes nas orientações monásticas (Cf. GONZALEZ, 1995, v. 2, p. 61). Dessa forma, é prudente lembrar que Agostinho pouco antes de sua adesão ao cristianismo, foi fortemente impactado pela história do monge anacoreta Antônio do Egito, conhecido como Santo Antão, relatado por ele mesmo no oitavo livro das Confissões. Agostinho narra que enquanto ele estava imerso nas consequências de uma possível adesão ao cristianismo, pois teria que abandonar prazeres, honras, cargos e mulheres, é visitado por um dignitário do império romano de naturalidade africana chamado Ponticiano. Este ao ver as cartas de Paulo sobre a mesa começa a relatar a história de vida de Antônio do Egito (Cf. AGOSTINHO, Confissões, VIII, 6, 14), que este teve contato pela leitura do livro "Vida e Conduta de Santo Antão" escrito pelo bispo católico Atanásio. Pelo testemunho escrito de Atanásio, Antônio do Egito viveu entre 251-269, nasceu rico, mas nunca se interessou em demasia em aproveitar a riqueza do pai. Quando ainda muito jovem, entre 18 a 20 anos, os pais morreram, e ao entrar em uma igreja escutou a leitura do Evangelho de Mateus 19: 21, que em síntese exorta a vender tudo e seguir a Cristo, o que antão faz reservando uma pequena parte da fortuna para cuidar da irmã menor. Todavia volta a entrar na igreja em outro momento e ouve a leitura de Mateus 6:34, passagem do sermão do monte em que Jesus orienta a não se preocupar com o dia de amanhã. Conta-nos Atanásio que depois dessa segunda experiência Antão distribuiu o restante dos bens, deixou sua irmã aos cuidados de uma casa de virgens para ser cuidada e educada, e começou a se preparar para a vida monástica (Cf. ATANÁSIO, Vida e Conduta de Santo Antão, I, 3). Segundo a narrativa de Atanásio Antão na intenção de aprender sobre a prática da vida monástica com outros monges mais experientes, principia no monaquismo cenobítico, e quando se sentiu preparado iniciou no monaquismo anacoreta (Cf. ATANÁSIO, Vida e Conduta de Santo Antão, I, 4 - I, 15). A vida desses monges era extremamente simples como nos descreve Justo Gonzalez: "A vida dessas pessoas era extremamente simples. Alguns cultivavam hortas, mas a maioria se sustentava tecendo cestas e esteiras que vendiam em troca de um pouco de azeite. [...] A dieta da maioria dos monges consistia em pão e, às vezes, frutas, legumes e azeite. Suas posses não excediam a vestimenta necessária e uma esteira para dormir" (GONZALEZ, 1995, v. 2, p. 67). Com relação ao desapego de bens materiais do monge Antão, conta-nos Atanásio: "Comia só uma vez por dia, depois do pôr-do-sol, e acontecia por vezes de tomar alimento apenas de dois em dois dias, muitas vezes até de quatro em quatro. Ora, seu alimento era pão e sal; a bebida água pura. [...] Para dormir, contentava-se com uma esteira, e na maior parte do tempo dormia na terra nua (ATANÁSIO, Vida e Conduta de Santo Antão, I, 7). Ao relatar o primeiro contato de Antão com as pessoas após vinte anos solitário no deserto, nos revela a aphatheia ante a quaisquer afetos: “[...] nele nem riso nem tristeza; a multidão não o perturbava, as muitas pessoas que o saudavam não lhe davam alegria excessiva: sempre igual a si mesmo governado pela razão [...] (ATANÁSIO, Vida e Conduta de Santo Antão, I, 14). Com uma leitura um pouco mais atenta das Confissões VIII, é perceptível o tremendo impacto da exposição de Ponticiano sobre Antão na compreensão de Agostinho sobre a vida cristã, e apesar de nos textos analisados e que analisaremos no corpo do texto não existir clara sinalização, entendemos ser perfeitamente possível que essa aparência de aphatheia estoica nos textos discutidos seja na verdade decorrente do forte efeito do testemunho de autoridades espirituais do quilate do Monge Antão, na medida em que é possível encontrar nos enfrentamentos das paixões e no desapego absoluto com relação aos bens materiais, certo ponto de encontro entre as máximas estoicas e as práticas dos monges anacoretas.
}

BRANDÃO, Ricardo Evangelista. Dilectio, resignação e injustiça: possibilidade de interpretar o amor como resignação e conformação com a injustiça, à luz de Santo Agostinho. Griot : Revista de Filosofia, Amargosa - BA, v.22 n.1, p.251-265, fevereiro, 2022 . 
tais medidas, nos dando a informação que nesse texto o hiponense entende que esse sentimento de inconformação é uma exceção, pois a regra é a resignação. Sem dúvida a perícope analisada não parece coerente com o amor bidimensional (a Deus e ao próximo) dos evangelhos sinóticos assumidos por Agostinho (Cf. AGOSTINHO, De civ. Dei, XIX, 23, 5; AGOSTINHO, In ep. Joan. ad Parthos, V, 3; AGOSTINHO, De ver. rel., 46, 87), pois como defender essa imperturbabilidade perante o sofrimento do outro e mesmo assim assumir o amor ao próximo como valor incondicionalmente oriundo da relação com o Sagrado? Uma forma de interpretar o fragmento preservando-o de possíveis incongruências seria interpretar que essa passividade que é regra, se refere exclusivamente aos sentimentos para não se perder a paz interior, e não a ação do cristão no socorro ao combalido. Embora tal compreensão não estaria fora de remotas possibilidades, o texto não é claro quanto a isso, de forma que tal interpretação poderia ser uma exegese criativa não autorizada pelo texto na intenção de preservar o autor de incoerências. Dessa forma, para evitar o risco de eisegese, se faz necessário o estudo de outros textos do filósofo em análise escritos sobre o assunto.

Um texto que lançará importante luz sobre o tema, escrito aproximadamente dois anos antes do texto outrora analisado, é o "Sobre os costumes da Igreja Católica e dos maniqueus"11, livro interessante pois construído em contexto de vida semelhante ao livro anterior, quando Agostinho após abandonar a categoria de ouvinte maniqueu, se converte ao cristianismo, decidindo confrontar a superioridade da nova fé com as falhas da fé apostatada. Rito contínuo, no capítulo vinte e sete do primeiro livro, o que trata dos costumes da igreja, Aurélio Agostinho na intenção de expandir a extensão do amor ao próximo, afirma que podemos dizer que amamos o próximo em duas dimensões: a corpórea e a da alma, pois o homem é esse composto de corpo e alma, logo, para amar o homem é necessário amá-lo integralmente e não delimitar a dimensão que lhe é mais conveniente (Cf. AGOSTINHO, De mor. Eccl. cath et mor. Man. I, 27, 52,53). Pela atenção que ele dá ao amor ao corpo, nas entrelinhas possivelmente está implícito a insistência de alguns cristãos que dizem amar o próximo se dedicando exclusivamente a alma do mesmo, ou seja, ensinando, exortando, aconselhando, orando pela salvação, etc. O problema não é o cuidado com a alma do outro, mas fazê-lo em detrimento do cuidado com a dimensão corpórea desse outro. Cuidar do corpo é: alimentar, saciar a sede, cuidar das feridas, vestir, dá abrigo, etc. Ou seja, o amor verdadeiro ao próximo, envolve toda essa preocupação e cuidado com a alma, mas também ação de cuidar do corpo do outro quando houver necessidade.

Nesse contexto, a questão deixada em aberto na análise do De vera religione é melhor esclarecida no texto atual objeto de nossa análise. Assim, em exortação acerca da importância

\footnotetext{
11 O De moribus Ecclesiae Catholicae et de moribus manichaeorum, foi escrito entre 387 - 388, logo, pouco mais de um ano após a sua adesão ao cristianismo. Obra dividida em duas partes, uma sobre os costumes da igreja e outro sobre os costumes dos maniqueus. O próprio Agostinho esclarece a motivação da obre em seu livro "Retratações" o qual transcrevemos: "Estando e Roma já batizado, e não podendo tolerar a jactância dos maniqueus a respeito de sua falsa e falaz continência ou abstinência com a qual, para enganar os ignorantes, colocavam-se superiores aos verdadeiros cristãos, aos quais não podem ser comparados, escrevi dois livros: um Sobre os costumes da Igreja Católica, o outro Sobre os costumes dos maniqueus" (AGOSTINHO, Retract. I, 7, 1). "Iam baptizatus autem cum Romae essem, nec ferre tacitus possem Manichaeorum iactantiam de falsa et fallaci continentia vel abstinentia, qua se ad imperitos decipiendos, veris Christianis, quibus comparandi non sunt, insuper praeferunt, scripsi duos libros, unum De moribus Ecclesiae catholicae, et alterum De moribus Manichaeorum" (AGOSTINHO, Retract. I, 7, 1 - PL 32). Dessa forma, trata-se de uma obra de cunho apologética, visto que ele pretende demonstrar que a santidade propagada pelos ensinos dos discípulos de Mani além de ser exterior, é muito inferior à santidade dos autênticos discípulos de Cristo (Cf. PRIETO, 2011, p. 208). É importante ressaltar que o hiponense viveu por nove anos na categoria de ouvinte na seita maniqueísta, de maneira que a conhecia com propriedade, de forma que sentiu a necessidade de esclarecer apologeticamente a falta de fundamento da moralidade maniqueia e os fundamentos da moralidade cristã. Ao fazer essa comparação entre as duas doutrinas morais, Agostinho acaba ensinando bastante sobre a filosofia cristã, e de forma clara e aprofundada nos explica o papel do amor e da relação desse amor com o socorro ao próximo na vivência cristã.
} 
do cuidado com as necessidades corpóreas do outro como evidência do amor ao próximo, afirma o filósofo cristão:

São misericordiosos quem por cortesia e humanidade oferecem o que é necessário para resistir a estes males e dores, ainda que alcance tal nível de sabedoria, que sua alma não se afete com dor ou tribulação alguma. Quem não sabe que a palavra misericórdia significa tornar miserável ou infeliz o coração que se aflige como mal dos outros? (AGOSTINHO, De mor. Eccl. cath et mor. Man. I, 27, 53) ${ }^{12}$.

Está presente no texto a ideia de que o sábio dispõe de total controle de suas emoções, de forma que possui controle racional de qualquer afecção, e, portanto uma forma de resignação gerada pela sabedoria. Contudo, o sofrimento alheio, quando é intenso, de forma que outrem se encontre em estado de penúria, existe uma natural tendência de afecção, que no fragmento citado igualmente está no controle do sábio. Entretanto, esse controle resignado com relação à inópia alheia, não significa inação. Agostinho reconhece que o termo misericordia significa compadecer-se pelo sofrimento dos miseráveis, todavia entende que existem pessoas que alcançaram tal nível de sabedoria que socorrem os miseráveis sem ser movidos por empatia, mas pelo simples dever de agir com bondade, uma forma de deontologia cristã. Contudo, mesmo nesse caso Agostinho entende que esses sábios por causa de não se permitir a inação, podem ser chamados de misericordiosos.

Se existiam algumas interrogações suspensas, entendemos que elas foram deveras respondidas, pois, a despeito da existência do ideal do sábio imperturbável em qualquer situação, inclusive ante o sofrimento alheio, há uma clara exortação de que isso não pode conduzir à inércia. Isso fica patente no contexto do fragmento citado, no qual o hiponense critica severamente os homens que se afastam dos miseráveis para não serem afetados com tal estado de sofrimento, e ao não serem abalados agem como se tal situação de dor alheia não existisse. Esses não agem com serenidade provinda da sabedoria, mas como uma frieza decorrente de falta de humanidade (Cf. AGOSTINHO, De mor. Eccl. cath et mor. Man. I, 27, 54). Na prática o pensador ressignifica o termo misericordia, como agir para afastar o sofrimento do próximo ao invés de sentir as estocadas das dores do próximo, de forma que apenas se abalar e nada fazer não seria de fato uma ação misericordiosa, mas apenas emocionalismo.

\section{Resignação e o amor ao próximo à luz das obras: In Epistolam Ioannis ad Parthos e De civitate Dei contra paganos}

No belíssimo texto "Comentário à Primeira Epístola de São João" (In Epistolam Ioannis ad Parthos tratactus decem) existe uma importante contribuição acerca do assunto proposto. $\mathrm{O}$ texto foi escrito em 416, período em que Agostinho já exercia o cargo de bispo efetivo de Hipona há aproximadamente 19 anos, período esse deveras conturbado no episcopado do filósofo, pois estava administrando animosidades decorrentes do cisma donatista ${ }^{13}$. Esse problema cismático

12 Quare illa omnia, quibus huiuscemodi malis incommodisve resistitur, qui officiose atque humiliter praebent, misericordes vocantur, etiamsi sapientes usque adeo sint, ut iam nullo animi dolore turbentur; nam quis ignoret ex eo appellatam esse misericordiam, quod miserum cor faciat condolescentis alieno malo? (AGOSTINHO, De mor. Eccl. cath et mor. Man. I, 27, 53 - PL 32).

${ }^{13} \mathrm{O}$ cisma donatista surge no início de século IV, liderado por Donato, em consequência da interpretação do comportamento que a igreja deveria ter em relação às pessoas que apostataram a fé, na época da última grande perseguição romana ao cristianismo desenvolvida pelo imperador Diocleciano. Os denominados donatistas entendiam que as pessoas que apostataram a fé entregando as escrituras às autoridades romanas devido ao decreto imperial, não deveriam ser mais aceitos como autoridades eclesiástica, e seus atos eclesiais não deveriam ser autenticados pela igreja. Assim, no ano 311 um grupo de cristãos liderados por Donato solicitaram a deposição do recém escolhido bispo de Cartago Ceciliano, afirmando que a sua ordenação não era legítima por ter sido realizada pelo bispo Félix que o grupo acusava de apostatar da fé na perseguição mencionada (Cf. CAIRNS, 1995, p. 
não era nada modesto em Hipona, pois a maioria da população da cidade era donatista, e na medida em que a sede episcopal defendia a perspectiva católica, a tensão e animosidade na igreja em Hipona tornaram desafiador ser titular dessa sede. A hostilidade era patente de ambos os lados, chegando em alguns casos mais radicais a ser violenta com os circunceliões do lado donatista, e com a força coercitiva do Estado pelo lado dos católicos (Cf. BROWN, 2005, p. 285287). O fato é que Agostinho estava no centro desse rio de animosidades, e no texto em questão defende a tese de que o amor genuíno, fruto de uma real conversão deve ultrapassar todas as barreiras, inclusive a da inimizade consequente do cisma presente no contexto. Todos devem ser incondicionalmente amados, sejam eles católicos ou donatistas ${ }^{14}$.

No sétimo tratado Agostinho faz uma exaltada exortação acerca do amor, afirmando a princípio que a própria expiação na cruz foi um ato de puro amor, pois Jesus não tinha a menor obrigação de ser cravado na cruz, e sendo filho de Deus teria o poder para evitar tal sofrimento, mas ele quis expiar a culpa de outros por esse terrível sofrimento, e ele quis por um ato de puro amor (Cf. AGOSTINHO, In ep. Joan. ad Parthos, VII, 2). Ato contínuo, o filósofo defende a resignação como uma forma de amor, ou melhor, como evidência do amor ao outro. Pois, Cristo, que sofreu todas as agonias da cruz sem ter feito nada para merecê-las, teria todos os motivos do mundo para se irar contra seus algozes, mas ao contrário disso os amou a todos, pedindo ao seu Pai que perdoasse seus ofensores. Ante essa forte colocação, questiona: "Se aquele que tinha o poder soberano não fez nenhuma ameaça de vingança, por que hás de ameaçar tu, que estás colocado sob o poder de outros?" (AGOSTINHO, In ep. Joan. ad Parthos, VII, 3) ${ }^{15}$.

É nítida no texto citado a marca da tensão vivida na época, pois ambos os partidos estavam com os sentimentos à flor da pele, chegando a imprecar ameaças aos cristãos do outro partido. A despeito dessa conjuntura, entendemos que essa compreensão, embora escrita movida pela situação, enquanto compreensão de Agostinho de como lidar com os infortúnios gerados por outros, não está restrito ao contexto. Assim, se exorta uma resignação pelo exemplo do filho de Deus, e pela constatação da pequenez humana. Pois, se o próprio Cristo nos horríveis sofrimentos na cruz não proferiu ameaças para quem o torturava, levando em consideração que sendo a segunda pessoa da santíssima Trindade é onipotente, quem somos nós para querer reparação ou vingança quando sofremos com a ação, mesmo que injusta dos outros. O texto faz questão de ressaltar que um dos motivos para a resignação seria a própria condição humana de estar sobre o poder de outros. Sabemos que no entorno do texto está presente a comparação com Deus que possui pleno poder, e mesmo assim se conformou com a humilhação imposta pela morte por tortura na cruz, todavia, ao mencionar a falta de poder dos homens reportando o fato de estarem sob o poder dos outros, poderia indicar apologia discreta a um resignar-se por sua posição hierárquica. Ou seja, com cuidado para não forçar demais os limites exegéticos do texto, poderíamos afirmar nas entrelinhas que um dos motivos para que o homem se conforme com os danos causados pelos outros seja o fato de estar submetido ao poder de outros. Na verdade esse não é o motivo principal presente no contexto, pois, o que levou Cristo a se entregar ao sacrifício expiatório não foi seu poder, mas seu amor incondicional, seu poder é utilizado para ressaltar seu amor, pois, ele teria poder para não aceitar a injusta situação, mas aceitou apenas por amor.

84). Como a solicitação não foi aceita, elegeram outro bispo, o Majorino, e a igreja de Cartago ficou com dois bispos, um donatista e outro católico, de forma que depois da morte de Marjorino, Donato o sucedeu na sede cismática (Cf. MARKUS, in: FITZGERALD, 2006, p. 440-444).

${ }^{14}$ Embora bem mais possa ser dito acerca da ocasião da obra, e do estilo de texto do comentário, as informações colocadas até aqui sobre o contexto são o suficiente para o que se pretende em nossa análise, não cabendo aqui fazer uma análise acurada acerca de todas as minúcias envolvidas nas possíveis intenções da obra.

15 "Si autem non minabatur qui potestatem habebat; tu quid minaris, quid sufflas in potestate aliena constitutus?" (AGOSTINHO, In ep. Joan. ad Parthos, VII, 3 - PL 35). 
Dessa forma, a submissão do homem a outros é usados nos textos não como o fator principal da resignação, pois esse é o amor, mas como um argumento a mais para incentivar a resignação pelo exemplo da conformação de Cristo. Mesmo não sendo o motivo principal, esse argumento da submissão ao poder dos outros para justificar a resignação causa certo incômodo, pois, permanece um espaço para se interpretar que o subalterno deveria se sujeitar às injustiças cometidas apenas pelo fato de sua condição de subalternidade.

Essa possibilidade de entendermos se de fato Agostinho defendeu no analisado comentário a resignação frente aos poderosos mesmo ante as injustiças, é parcialmente aprofundada no oitavo tratado. Pois, no tratado em questão interpretando vários versículos da Primeira Epístola de São João que admoestam que o amor ao próximo não pode ser apenas teórico, mas deve conduzir o cristão à prática benevolente, afirma que até mesmo essa benevolência deve ser pensada. Visto que embora seja um eco da dilectio auxiliar ao próximo que necessita, não devemos desejar a existência de miseráveis para ter oportunidade de exibir a nossa benevolência ${ }^{16}$, logo, deve-se desejar a igualdade para que o que ajuda não se sinta superior ao outro, nem para que o auxiliado se sinta inferior: "Ele necessita, tu o ajudas; mas por ter ajudado, tu te imaginas superior àquele a quem ajudas. Deseja ser igual, para que ambos estejam sujeitos Àquele a quem nada se pode dar" (AGOSTINHO, In ep. Joan. ad Parthos, VIII, 5) ${ }^{17}$. O que seria esse: Opta aequalem - Deseja ser igual? Agostinho chega a mencionar a Nova Jerusalém onde não existirá miséria de nenhum tipo, mas levando em consideração que essa igualdade da Nova Jerusalém é para a eternidade, e a igualdade almejada refere-se no contexto às necessidades da vida terrena, questionamos: seria um comportamento que expressa a dilectio apenas o querer ser igual ao outro? Ou está implícito a ação para tentar de alguma forma agir para concretizar esse desejo? Entendemos que embora o filósofo não expresse claramente, pelo contexto do fragmento, a ação para tornar concreto o desejo de igualdade é necessária, pois, permanecer apenas no desejo de igualdade poderia equivaler ao amar só no discurso e não na prática, criticado nessa carta de São João por ele comentada ${ }^{18}$.

Destarte, ninguém deve estar acima do outro, pois, todos foram criados à imagem e semelhança de Deus, ou acaso o Criador ao ordenar a criação disse que os homens deveriam dominar outros homens? (Cf. AGOSTINHO, In ep. Joan. ad Parthos, VIII, 6). Sabemos que embora esse não tenha sido o plano original do Ordenador supremo, a desigualdade adentrou na ordem pelo pecado, de forma que os homens não se conformam em dominar a criação não humana, e se comprazem ao se pensarem superiores aos outros. Ciente de que essa desigualdade apenas penetrou na ordem humana por meio do mal moral, não seria obrigação do homem cristão não se resignar com essa marca do pecado, e ao não se conformar se dispor a ser agente

\footnotetext{
${ }^{16}$ Em diversos trechos de seu "Comentário da primeira epístola de João", que é uma dos mais belos e profundos tributos ao amor entre as obras do mestre de Hipona, é dito que esse amor inevitavelmente envolve benevolência, de forma que não consiste em apenas um bom sentimento romanticamente verbalizado, mas algo que envolve ação de quem ama em prol do objeto amado. No capítulo cinco do sétimo tratado, de forma dura, contudo coerente insiste que se deve ser benevolente para com os que necessitam, todavia, jamais se deve desejar a miséria alheia para exercitar a benevolência, pois isso é qualquer outra coisa menos dilectio (Cf. AgOSTINHO, In ep. Joan. ad Parthos VIII, 5). Essa forma elevada de amor, a despeito de ser concretizada na ajuda ao próximo, não deve ter como fim nos fazer sentir melhores pessoas, mas o cuidado desinteressado para com o outro. Não que o cristão não deva se sentir bem em socorrer quem precisa, pois em certa medida demonstra que foi realizada por uma pessoa que se compraz com a melhora do outro, mas isso não pode ser o sentimento protagonista na ação, mas o bem em si mesmo ao próximo, pois se assim não for, essa ação benevolente pode se tornar um egoísmo disfarçado de altruísmo.

17 "Ille indiguit, tu impertitus es; quasi maior videris quia tu praestitisti, quam ille cui praestitum est. Opta aequalem, ut ambo sub uno sitis cui nihil praestari potest" (AGOSTINHO, In ep. Joan. ad Parthos, VIII, 5 - PL 35 ).

${ }_{18}$ Eis o trecho da Primeira carta de São João que exorta sair do discurso para a prática do amor cristão, que sem dúvida impactou o hiponense em seu comentário: "Se alguém, possuindo bens deste mundo, vê seu irmão na necessidade e lhe fecha o coração, como permanecerá nele o amor de Deus? Filhinhos, não amemos com palavras nem com a língua, mas com ações e em verdade" (I João, III, 17, 18).
}

BRANDÃO, Ricardo Evangelista. Dilectio, resignação e injustiça: possibilidade de interpretar o amor como resignação e conformação com a injustiça, à luz de Santo Agostinho. Griot : Revista de Filosofia, Amargosa - BA, v.22 n.1, p.251-265, fevereiro, 2022. 
que propicie a igualdade? Levando em consideração que ao falar opta aequalem Agostinho estava justamente criticando certa forma de benevolência, a possibilidade da igualdade não ser apenas por atos benevolentes é grande. Se a nossa leitura estiver correta, temos indícios de uma defesa de uma ação social voltada para a autonomia do indivíduo, para que ele deixe de necessitar do outro e alcance a dignidade de não ser inferior a outrem. Assim, mesmo ante a ideia teológica do desarranjo da ordem que gerou a submissão de um homem para com outro, o texto em análise defende opta aequalem na tentativa de retornar à ordem divinamente orientada, onde todos os homens são iguais sendo inferiores apenas ao Criador, que por conceito nada necessita, sendo o único necessário.

No contexto da perícope em análise, o filósofo de Hipona destaca diversos exemplos de que o cristão deve afastar a tentação de sentir-se superior ao outro ante a dependência dele à sua ajuda, utilizando até mesmo o eloquente exemplo da relação entre o mestre e o discípulo. Pois, o mestre deve trabalhar para que seu discípulo adquira autonomia para pensar por si mesmo, e nunca permitir que essa relação mantenha o discípulo sempre na dependência do mestre para o saber, alimentando assim uma forma de submissão na sabotagem, mesmo que não consciente, da autonomia do discípulo (Cf. AgOSTINHO, In ep. Joan. ad Parthos, VIII, 8). Entendemos que essa não aceitação do sentimento de superioridade do discípulo de Cristo frente aos auxiliados por ele, está devidamente demonstrada nos textos supra analisados, todavia surge uma questão relacionada: poderíamos estender essa não aceitação aos que não estão sendo frutos de nossos atos de misericórdia? Ou seja, até que ponto poderíamos aplicar essa não resignação às relações de submissões sofridas em outras relações que não estamos envolvidos diretamente, ou até mesmo naquelas em que nós estamos em submissão a outros?

Embora possamos querer uma visão mais progressista de Agostinho, com uma defesa para que o cristão não aceite a submissão, entendemos que na situação retratada, o cristão, visto que possui pela fé certeza da vida eterna, deve se resignar por essa certeza. Temos fortes indícios disso no tratado VIII, 11, onde no contexto de apaziguar as desavenças entre católicos e donatistas, afirma que se deve perdoar qualquer mal praticado contra si, fiado na esperança da vida eterna, e na convicção de que se Deus tudo pode, e poderia evitar determinado dano gerado a você e decide permitir, a Sua permissão deve ter algum propósito que desconhecemos (Cf. AgOSTINHO, In ep. Joan. ad Parthos, VIII, 11).

A convicção mencionada supra, não deve conduzir o cristão à passividade ante ao erro, de forma que em fragmento que traz os traços do cisma donatista, Agostinho afirma que o amor incondicional recebido após a real conversão não significa compactuar com erro, mas justamente repreender por amor: "Se quiseres conservar a caridade, irmãos guardai-vos, sobretudo de pensar que ela seja sem iniciativa, sem atividade e que para conservá-la basta certa mansidão que digo - não mansidão, mas antes indolência e moleza (AGOSTINHO, In ep. Joan. ad Parthos, VII, 11) ${ }^{19}$. E após alguns exemplos de situações que em síntese apresentam que amar de forma verdadeira não prescinde a repreensão, arremata: “[...] Isso não é caridade, é tibieza. Que a caridade seja ardente para corrigir, para repreender (AGOSTINHO, In ep. Joan. ad Parthos, VII, 11 $)^{20}$. Dessa forma, no que tange à correção ao próximo, o amor não gera a resignação, mas antes a correção, pois o amor não pode ser confundido com a aceitação irrestrita de qualquer situação. Essa eloquente perícope coloca um limite: o erro do próximo, pois, a indulgência com o erro alheio não pode ser conceituado como amor, mas como languor (frouxidão, moleza, tepidez).

19 "Si qui forte vultis servare caritatem, fratres, ante omnia ne putetis abiectam et desidiosam; nec quadam mansuetudine, imo non mansuetudine, sed remissione et neglegentia servari caritatem" (AGOSTINHO, In ep. Joan. ad Parthos, VII, 11 - PL 35 ).

20 "[...] non est ista caritas, sed languor. Ferveat caritas ad corrigendum, ad emendandum" (AGOSTINHO, In ep. Joan. ad Parthos, VII, $11-P L 35)$. 
Nos exemplos elencados por Agostinho em sua argumentação temos a correção: ao servo, filho e ao vizinho, todos realizando atos incorretos que devido ao amor deveriam ser repreendidos. A correção ao filho e ao servo está na esfera íntima da família, e em relação que se tem certa autoridade natural para a repreensão, todavia, ao repreender o vizinho a situação muda completamente de figura. Já que é proposto nesse fragmento a não aceitação de erros praticados por vizinhos, é possível sem forçar muito os limites exegéticos do texto, estender essa não aquiescência a atos injustos em geral dos outros. Logo, não seria uma consequência natural do amor se resignar com as injustiças provocadas aos outros, pois tais atos injustos igualmente se constituem em erros passíveis de serem repreendidos ${ }^{21}$, de maneira que ser resignado ante um ato de injustiça praticado equivaleria ao languor. Como essa interpretação supra não foi distintamente apresentada pelo pensador de Hipona, é possível que seja apenas isso de fato, uma interpretação. Assim, convém nas linhas que nos restam, iluminar o assunto em fragmentos da última obra a ser analisada nessa investigação.

Para concluir as nossas reflexões acerca do assunto em estudo, analisaremos alguns fragmentos do livro XIX do De civitate $D e i^{22}$ que sem dúvida nos auxiliará a pensar na perspectiva de um Agostinho no ápice de sua maturidade intelectual, maturidade essa que lhe possibilitou escrever um verdadeiro texto de filosofia da história, costurando uma impressionante gama de assuntos sob a perspectiva da filosofia cristã.

A partir do capítulo treze do livro XIX, o filósofo na intenção de exortar acerca da paz eterna, elabora interessante reflexão acerca da paz que toca lateralmente no objeto investigado. Aristóteles em sua Ética a Nicômaco já dizia que todas as coisas possuem seu próprio bem, na medida em que tudo o que existe enquanto existe possui seu telos natural, e esse telos é o seu bem (Cf. ARISTÓTELES, Ética a Nicômaco, I, 1, 1094a). Em toada semelhante, Agostinho pensa que igualmente existe uma tendência em toda a natureza, como se fosse um pondus natural de tudo o que existe, a paz. A felicidade sem dúvida é objeto de busca de todos os homens, mas até que ponto seria possível a felicidade sem a paz? Além disso, podemos afirmar que a paz é ainda mais universal que a própria felicidade, pois essa última é objeto de busca consciente, enquanto a paz além de não se restringir apenas a busca humana, pois, é uma tendência comum aos homens, animais e plantas, nem sempre é busca consciente, além do fato de que o homem a consegue encontrar mesmo nas situações mais inóspitas. A despeito de estarmos habituados a conceituar a paz como certa tranquilidade oriunda da ausência de conflitos, o pensador de Hipona acrescenta que essa ausência de conflitos de diversas ordens acontece por certo ordenamento, ou seja, cada coisa encontra a sua específica paz ao ocupar seu devido lugar natural ${ }^{23}$.

21 Na obra "Dos Deveres", Cícero classifica a injustiça em dois tipos, a que se pratica com a intenção deliberada de cometer atos
injustos, e a que se pratica por inação, ou seja, quando se tem o poder para evitar um ato injusto, mas nada faz (Cf. CÍCERO,
Dos Deveres, I, 6). Na perspectiva de Agostinho igualmente a inação quando se possuía a potência para algo fazer, é algo indigno
do amor cristão, logo, um ato de injustiça. É como se por inércia, o cristão que possui o dever de amar com o amor de Deus, se
tornasse cúmplice do ato injusto.
22 A De civitate Dei, foi escrito entre os anos 413 a 426 , portanto, três anos após a queda de Roma por Alarico. A obra foi escrita
com o incentivo de seu amigo e irmão de fé Marcelino, e a intenção fica absolutamente clara já nos primeiros capítulos do
primeiro livro (Cf. AGOSTINHO, De civ. Dei, I, l-10). Dessa forma, ao sair em defesa do cristianismo, desenvolve uma
interpretação da história na perspectiva da fé cristã, escrevendo a primeira teologia e filosofia da história (Cf. LEÃO, In.
AGOSTINHO, 2000, p. 17 ).
23 Segundo Agostinho a paz é uma tendência natural de tudo o que existe, pois de alguma forma tudo tende para o seu lugar
natural na ordem, essa tendência permanece mesmo depois da queda. Logo, nem sempre a paz buscada é aquela presente na
ordem original, mas uma deformada ou adaptada à nova ordem estabelecida por consequência do pecado. Portanto, todos
indistintamente buscam a paz, até mesmo quem propõe uma guerra não o faz pela guerra em si mesma, mas para alcançar a paz,
paz essa segundo seus propósitos. No corpo, a paz se manifesta com o funcionamento harmônico de suas partes em relação com a
alma, e na família a paz acontece quando harmonicamente a hierarquia de obediência e funções é respeitada. A mesma coisa
261

BRANDÃO, Ricardo Evangelista. Dilectio, resignação e injustiça: possibilidade de interpretar o amor como resignação e conformação com a injustiça, à luz de Santo Agostinho. Griot : Revista de Filosofia, Amargosa - BA, v.22 n.1, p.251-265, fevereiro, 2022. 
Sabemos que a inteligência suprema do Criador ao tudo criar, pensou e estabeleceu uma ordem natural para cada criatura em particular, e para a totalidade da criação em suas relações e inter-relações holísticas, todavia, devido à queda, principalmente, mas não exclusivamente na esfera humana, essa ordem foi alterada para encaixar as consequências do pecado, o que tornou mais difícil ocupar seu lugar na ordem e, por conseguinte alcançar a paz. Mesmo com as consequências da queda, que gerou entre outras coisas o sofrimento, a miséria, as desigualdades sociais, etc., o ser humano permanece, conscientemente ou não, buscando a paz, ou melhor, se adaptando resignadamente à nova ordem. Como nos esclarece emblematicamente o pensador cristão refletindo acerca da paz na miséria e sofrimento:

Portanto, como os miseráveis, enquanto tais, não estão em paz, não gozam da traquilidade da ordem, isenta de turbações, mas, porque merecida e justamente miseráveis, mesmo na miséria não podem estar fora da ordem [...]. Neles há, portanto, certa tranquilidade na respectiva ordem e, por conseguinte, certa paz. São miseráveis, porque, embora estejam onde devem estar, não estão onde não se veriam precisados de sofrer. São mais miseráveis, se não estão em paz com a lei que rege a ordem natural (AgOSTINHO, De civ. Dei, XIX, 13, 1) ${ }^{24}$.

Dessa forma, na medida em que a paz é consequência de cada coisa estar em seu devido lugar, com o advento do pecado, dor, miséria e sofrimento passaram a ser partícipes da ordem, tendo assim seu devido lugar na vida humana adaptada à nova ordem. Agostinho percebe a paz na miséria com certa dubiedade, pois, se por um lado a miséria gera falta de tranquilidade por não fazer parte da ordem original, na medida em que foi incorporada na ordem, é possível ter paz mesmo em sofrimento. De fato é perceptível a perspicácia do hiponense na observação do comportamento humano, dado que de fato ninguém fica satisfeito no estado de miséria, e sem dúvida essa inconformação gera falta de paz, contudo, a permanência prolongada nessa condição faz com que a pessoa encontre, por sobrevivência, espaço em sua vida para encontrar certa paz na resignação tranquila de uma consciência de que tal situação é inalterável ou aparentemente inalterável ${ }^{25}$.

acontece na relação entre patrão e empregado, quando a cada um faz a sua parte respeitando a hierarquia de obediência, temos paz nessa relação, rito contínuo a paz na cidade se dá pela concórdia entre governantes e governados (Cf. AGOSTINHO, De civ. Dei, XIX, 12 -13). E suma essa busca, que é mais uma tendência, é anseio presente em toda a criação, como arremata Agostinho: "A paz de todas as coisas é a tranquilidade da ordem. A ordem é a disposição dos seres iguais e desiguais que distribui a cada um os seus lugares" (AGOSTINHO, De civ. Dei, XIX, 13, 1).

24 "Proinde miseri, quia, in quantum miseri sunt, utique in pace non sunt, tranquillitate quidem ordinis carent, ubi perturbatio nulla est; verumtamen quia merito iusteque sunt miseri, in ea quoque ipsa miseria sua praeter ordinem esse non possunt; [...] ac per hoc inest eis ordinis nonnulla tranquillitas, inest ergo nonnulla pax. Verum ideo miseri sunt, quia, etsi in aliqua securitate non dolent, non tamen ibi sunt, ubi securi esse ac dolere non debeant; miseriores autem, si pax eis cum ipsa lege non est, qua naturalis ordo administratur" (AGOSTINHO, De civ. Dei, XIX, 13, 1 - PL 41).

25 O filósofo e economista contemporâneo Amartya Sen em seu magnífico texto "Desigualdade Reexaminada", adverte que um aparente estado de satisfação e prazer não pode ser indício real de bem estar, pois as pessoas expostas por tempo prolongado a um estado de penúria, não se lastima por grande período de tempo, na medida em que ante a inalterabilidade da situação buscam limitar suas aspirações, encontrando satisfação e prazer em situações tão miseráveis que inviabilizam um real bem-estar: "O problema é particularmente grave no contexto das desigualdades e privações arraigadas. Uma pessoa totalmente desprovida, levando uma vida bastante limitada, poderia não parecer pobre em termos de uma métrica mental do desejo e sua satisfação, se a miséria for aceita com silenciosa resignação. Em situação de privação duradoura, as vítimas não continuam lamentosas e pesarosas todo o tempo, e muito frequentemente fazem grandes esforços para tirar prazer de pequenas dádivas e reduzir desejos pessoais a modestas - "realistas" - proporções" (SEN, 2001, p. 96). Na mesma toada, a filósofa Adela Cortina em seu texto "Aporofobia, a aversão ao pobre", afirma que os pobres ao se resignarem com a miséria em que vivem, ficam satisfeitos por quaisquer pequenas ajudas ou melhoras, de forma que muitas vezes ficam por meios de pacífica resignação pouco conscientes de sua situação de injustiça social, tendo assim que ser conscientizados da indignidade da situação em que estão expostos (Cf. CORTINA, 2020, p. 48, 49).

BRANDÃO, Ricardo Evangelista. Dilectio, resignação e injustiça: possibilidade de interpretar o amor como resignação e conformação com a injustiça, à luz de Santo Agostinho. Griot : Revista de Filosofia, Amargosa - BA, v.22 n.1, p.251-265, fevereiro, 2022. 
Segundo a perícope analisada, alguma forma de paz é possível mesmo em meio a mais agonizante miséria, ao tentar na conformação e aceitação desse estado banir expectativas de iminentes mudanças para possuir certa tranquilidade. A paz nesse formato supra descrita é exatamente correspondente ao conceito de nosso objeto de pesquisa, a resignação. Pois, essa paz acontecerá exatamente quando por meio da aquiescência da inalterabilidade de tal situação, se aceita de forma tranquila a situação de miséria. Assim, segundo Agostinho, a resignação não só é possível em estado de extrema adversidade, como seria uma condição humana se resignar em algum momento com tais circunstâncias para ter alguma paz, pois, se isso não acontecer, a miséria seria superlativada, na medida em que se sofreria pelo estado de miséria e pela constante inconformação ante certa estabilidade desse cenário. A despeito de no analisado fragmento não se fazer referência a uma possível relação entre resignação e o amor, achamos por bem analisálo, porquanto, fica evidenciado que a resignação em situações extremas acaba se tornando o único meio possível para a paz, e como já mencionamos sem paz a felicidade é impossível. Além disso, apesar do fato de que embora o amor não seja textualmente mencionado, não podemos descartar a sua presença nas entrelinhas, posto que o texto também discorre sobre a situação de miséria mesmo para os cristãos, que ao serem cristãos foram inundados com o amor de Deus, irradiando esse superior amor em todas as situações de sua vida.

\section{Considerações finais}

É perceptível em nosso pensador, quando se trata de injustiças geradas a si, certa resignação gerada pela imersão no amor, por vários motivos declarados e não declarados. Entre os declarados poderíamos elencar: a certeza na vida eterna em que existirá a verdadeira justiça, e que o próprio Deus lhe consolará enxugando as suas lágrimas, como retrata a bela imagem no livro do Apocalipse (Cf. Apocalipse, XXI, 4); a imitação do perfeito amor de Cristo, que não se enfureceu mesmo no calvário em que era o único justo sofrendo por uma sentença injusta, tendo poder para desfazer o sofrimento e castigar seus algozes; a resignação trazida pela própria conversão no verdadeiro amor, que o faz ter um temperamento diferente ante ao sofrimento, percebendo um propósito divino por trás do sofrimento. Entre os motivos não declarados, e que por tanto interpretamos no silêncio de possíveis contextos, e que por esse motivo pedimos vênia máxima caso estejamos forçando os limites exegéticos do assunto, pensamos que Agostinho tinha enorme responsabilidade quando falava e escrevia ao povo. Pois, ele estava em uma comunidade de extrema desigualdade social, com pessoas em estado de profunda miséria vivendo literalmente da misericórdia e migalhas dos ricos e da igreja. Nessa situação, levando em conta a força das palavras de um bispo na região, a responsabilidade se redobra, pois um sermão mal interpretado poderia gerar consequências desastrosas incentivando o embate dos pobres para com os ricos, que naquele contexto, poderia ser muito pior para os pobres. Naquelas circunstâncias a resignação e o apelo ao auxílio do outro, foi a alternativa mais prudente.

Todavia, quando as injustiças em questão são as executadas contra o nosso próximo, não se exorta uma resignação, aliás, o amor gera uma irresignação para com a dor do outro, levando esse que verdadeiramente foi imerso no amor divino à ação. É óbvio que em hipótese alguma estamos discorrendo sobre alguma ação revolucionária contra as instituições que geraram o estado de injustiça, mas em se comover com a dor do próximo, partindo assim para ações misericordiosas.

Em suma, evidenciou-se nessa pesquisa que as misérias, dores, desigualdades sociais, injustiças, etc., são oriundas da desordem gerada pela introdução do mal no mundo. Todavia, se por um lado existe uma resignação gerada por uma adesão ao amor de Deus quando esse 
sofrimento é sofrido por si, por outro lado, quando essas penúrias são sofridas pelo próximo, devido à esse mesmo amor, o hiponense torna regra uma irresignação que conduz a uma ação para dirimir o sofrimento e encontrar condições para produzir igualdade e bem-estar. 


\section{Referências}

AGUSTÍN, San. De las costumbres de la Iglesia catolica y de las costumbres de los Maniqueos. In: Obras completas de San Agustín. ed. bilíngüe. Trad., introd. y notas de Teófilo Prieto. Madrid: La Editorial Católica / BAC, 2011. tomo IV, p. 207-388.

AGUSTÍN, San. De la verdadera religion. In: Obras completas de san Agustín. ed. bilíngüe Trad, introd. y notas de Victorino Capánaga. Madrid: La Editorial Catolica/BAC, 2011. tomo IV, p. 3-203.

AGUSTÍN, San. Exposición de la epístola de San Juan a los Partos. In: Obras completas de San Agustín.Trad., introd. y notas de Jose Moran. ed. bilíngue. Madrid: La Editorial Católica / BAC, 1959, vol. XVIII, p. 192-362.

AGUSTÍN, San. La Ciudad de Dios. In: Obras completas de San Agustín. Trad., introd. y notas de Jose Moran. ed. bilíngue. Madrid: La Editorial Católica / BAC, 1958, vol. XVII, Libros XIII-XXII. AGUSTÍN, San. Las confesiones. In: Obras completas de san Agustín. 9. ed. bilíngüe. Trad. de Angel Custodio Vega. Madrid: La Editorial Catolica/BAC, 2013. tomo II, 629 p.

AGUSTÍN, San. Las retractaciones. In: Obras completas de san Agustín. ed. bilíngüe Trad, introd. y notas de Teodoro C. Madrid. Madrid: La Editorial Catolica/BAC, 1995. tomo XL, p. 593-833.

ARISTÓTELES. Ética a Nicômaco. Trad. de Leonel Vallandro. São Paulo: Abril Cultural, 1973.

ATANÁSIO, Santo. Vida e conduta de Santo Antão. Trad. de Orlando Tiago Loja Rodrigues Mendes. 2. ed. São Paulo: Paulus, 2010.

BÍBLIA. Português. A Bíblia de Jerusalém. Trad. de Sociedade Bíblica Católica; Paulus. São Paulo: Paulus, 1985.

BROWN, Peter. Santo Agostinho, uma biografia. Trad. de Vera Ribeiro. Rio de Janeiro: Record, 2005. CAIRNS, Earle E. O Cristianismo através dos séculos: uma história da igreja cristã. 2. ed. Trad. de Israel Belo de Azevedo. São Paulo: Vida Nova, 1995.

CAPANAGA, Victorino. Cuadro Cronológcio de las Obras de San Agustin. In: Obras completas de San Agustín. 6. ed. bilíngüe.Trad. introd. y notas de Victorino Capanaga. Madrid: La Editorial Católica / BAC, 1994. tomo I, p. 384-387.

CÍCERO. Dos deveres. Trad. de Alex Marins. São Paulo: Editora Martin Claret, 2005.

CORTINA, Adela. Aporofobia, a aversão ao pobre: um desafio para a democracia. Trad. de Daniel Fabre. São Paulo: Editora Contracorrente, 2020.

EPICTETO. Manual: recomendações estoicas para o bem viver. Trad. de José R. Seabra Filho. Belo Horizonte: Edições Nova Acrópole, 2016.

FERREIRA, Aurélio Buarque de Holanda. Novo dicionário da língua portuguesa. 2. ed. Rio de Janeiro: Editora Nova Fronteira, 1986.

GONZALEZ, Justo L. E até aos confins da terra: uma história ilustrada do Cristianismo. Trad. de Hans Udo Fuchs. São Paulo: Vida Nova, 1995. v. 2.

LEÃO, Emmanuel Carneiro, In. AGOSTINHO, Santo. A cidade de Deus: contra os pagãos. 5. ed. Trad. de Oscar Paes Leme. Petrópolis: Vozes; São Paulo: Federação Agostiniana Brasileira, 2000. Parte I.

(Coleção Pensamento Humano).

MARKUS, Robert A. Donato, Donatismo. In: FITZGERALD, Allan. (org.). Diccionario de San Agustín: San Agustín a travésdeltiempo. Burgos: Monte Carmelo, 2006. p. 440-445.

PRIETO, Teófilo P. Introducción: De las costumbres de la Iglesia catolica y de las costumbres de los Maniqueos. In: Obras completas de San Agustín. ed. bilíngüe. Trad., introd. y notas de Teófilo Prieto. Madrid: La Editorial Católica / BAC, 2011. tomo IV, p. 204-227.

REALE, Gilvanni. História da filosofia antiga. 2. ed. Trad. de Marcelo Perine; Henrique Cláudio de Lima Vaz. São Paulo: Loyola, 1994. vol. IV, 608 p.

SEN, Armatya Kaumar. Desigualdade Reexaminada. Trad. de Ricardo Doninelli Mendes. Rio de Janeiro: Record, 2001.

Autor(a) para correspondência / Corresponding author: Ricardo Evangelista Brandão. ricardobrand75@gmail.com 